\title{
Wishing to Be Interviewed in Henry James's The Reverberator
}

\author{
By Matthew Rubery, \\ University of Leeds
}

When Henry James wrote about the age of "newspaperism" he was really writing about the "age of interviewing" (CN 86). While newspapers had existed for over two centuries, the interview was a controversial invention of the late-nineteenth-century press that dramatically influenced the way audiences thought about private life. The public's willingness to share their most intimate experiences with journalists through this conversational form was even more alarming to James than the invasion of privacy by newspapers. Matthias Pardon of The Bostonians (1885-86) has been taken to embody the invasive style of American journalism described in James's notebooks: "There must, indispensably, be a type of newspaper man-the man whose ideal is the energetic reporter. I should like to bafouer the vulgarity and hideousness of this-the impudent invasion of privacy-the extinction of all concept of privacy, etc." (CN 19). The notebooks characterize the loss of privacy in a way that attributes to the overzealous reporter sole responsibility for any revelations to come in the novel. Pardon begins his career in just such a fashion by collecting potentially scandalous names from hotel registers, although he makes his reputation through nothing more intrusive than speaking with hotel guests on behalf of The Boston Evening Transcript:

[He] was the most brilliant young interviewer on the Boston press. He was particularly successful in drawing out the ladies; he had condensed into shorthand many of the most celebrated women of his time-some of these daughters of fame were very voluminous-and he was supposed to have a remarkably insinuating way of waiting upon prime donne and actresses the morning after their arrival, or sometimes the very evening, while their luggage was being brought up. (BO 116)

While lurking about the hotel might imply a journalistic invasion of privacy, as culling names from the hotel register certainly does, we should not disregard the self-promotion of these "voluminous" prime donne. The assumption that Pardon obtains 
these responses through an invasion of privacy greatly underestimates the desire for publicity on the part of his respondents. Pardon's invasions of privacy go no further than a series of inappropriate questions: " $[\mathrm{H}] \mathrm{e}$ asked for revelations of the vie intime of his victims with the bland confidence of a fashionable physician inquiring about symptoms" (131). The voluntary replies given to the interviewer show a very different side to the alleged victims who, as it turns out, are predisposed to share their private lives with anyone willing to listen.

James rarely disguised his hostility toward the period's journalism for its emphasis on personalities, lifestyles, and gossip, or what British journalist Stephen Stapleton characterized as the "desire for peeps into the boudoirs and drawing-rooms of the polite world" (102). Critical assessments of James's relation to the print culture of his time initially promoted three main ideas: first, that journalism is a foil against which to distinguish "high" artistic value or the Jamesian aesthetic; second, that when James makes use of popular materials he does so ironically, even subversively; and third, that when James criticizes the press he is taking an ethical stance against the invasion of privacy. ${ }^{1}$ While James's involvement with mass culture has since been reconsidered, recent work has upheld this last point about one's right to be left alone even while calling into question the very opposition between publicity and privacy. Studies of journalistic inquiry by Brook Thomas and Richard Salmon, for example, demonstrate how commercial media incorporated the resistance to privacy in order to stage its subsequent violation. These studies might be said to perpetuate the image of the journalist as a transgressive figure intent on the kind of public exposure proposed by Gustave Flaubert's satiric definition of "celebrities": "Find out the smallest details of their private lives, so that you can run them down" (297). However, the context of nineteenth-century newspaper production suggests a different interpretation. The supposedly invasive methods used by these figures were among journalism's least invasive techniques since the success of the interview depended upon the cooperation of the respondent.

Journalists on the lookout for headlines are everywhere in James, though it may come as a surprise to realize that few of these journalists are responsible for the indiscretions that make up James's plots. The initial diversity of James's journalists-as editors, reporters, columnists, and correspondents-disguises their ultimate uniformity when it comes to the practice of interviewing. Nearly all of James's journalists are interviewers in some capacity: Matthias Pardon in The Bostonians, George Flack in The Reverberator (1888), Mr. Morrow in "The Death of the Lion" (1894), the unnamed narrator in "John Delavoy" (1898), Merton Densher in The Wings of the Dove (1902), and Maud Blandy and Howard Bight in "The Papers" (1903). Even a correspondent such as Henrietta Stackpole in The Portrait of a Lady (1880-81) relies upon the method for "chatty" society letters to The New York Interviewer, the telling name of the American journal for which she writes. Stackpole and her fellow journalists have at one time or another been interpreted as the author's protest against invasions of privacy. "My poor Henrietta," says Isabel Archer, "you've no sense of privacy" ( $P L$ 82). Yet it is the interviewee who is the greatest threat to privacy in James's novels. "Ah, do draw me out!" exclaims Ralph Touchett. "So few people will take the trouble" (84). What Ralph says facetiously will be repeated by other characters across James's novels without a trace of irony. The press can hardly 
be held responsible for those readers whose desire for publicity outweighs any sense of privacy. The Bostonians gives the best example of this peculiarly modern type in Selah Tarrant, of whom we are told, "The wish of his soul was that he might be interviewed" (97).

The distinction between interviewing and reporting may seem to make little difference at first glance, but any discussion of privacy rights must acknowledge that in James's fiction it is not the journalist who poses the greatest threat to privacy but rather the public itself. Journalism practices arising at the end of the nineteenth century were a problem for traditional defenses of privacy since, unlike investigative reporting, the interview was rarely an invasion of private life. ${ }^{2}$ On the contrary, James's narratives direct attention to people's willingness to share the most intimate details with an unseen audience-a phenomenon described by Richard Sennett as the "boundaryless self" (262) — in a way that ran counter to James's own preference for impersonal narration. The Reverberator, James's only novel devoted exclusively to newspaper journalism, was written during the very decades in which the personal interview established itself as a means of self-representation that would eventually become a defining feature of the "interview society" of the twentieth century (3). Hence this novel addresses a pattern of behavior whose significance extends well beyond the invasions of privacy for which it has usually been taken. By shifting attention away from journalism's production to its reception, James's novel examines the kinds of reading appropriate to a culture in which audiences accustomed to reading about other people in the newspapers now wanted to read about themselves. The Reverberator suggests that the interview may be a problem whose implications reach well beyond the limited interaction with the journalist in James's novel to all conversation involving the selective disclosure of information with an unseen audience in mind.

The personal interview has become such standard practice for today's news media that it is easy to forget how controversial its introduction was for audiences in the nineteenth century. The interview was not practiced in America until the 1860s or in England until the 1880s. Some historians cite as the first interview James Gordon Bennett's questioning of Rosina Townsend, a witness in the Ellen Jewett murder case, for the New York Herald in 1836. Nils Gunnar Nilsson's "The Origin of the Interview" establishes that during the nineteenth century the word "interview" went from meaning a face-to-face meeting to "the published result of a meeting between a representative of the press and someone whose views are related verbatim or with indirect quotations" (708). American penny papers of the 1830s adopted from the English popular press's coverage of courtroom trials two techniques, humorous treatment and verbatim testimony, which would eventually contribute to methods of interviewing. Reporters had used elements of the interview such as direct quotation and the question-and-answer format only sporadically up to this point. As Bennett's unofficial deposition of Townsend demonstrates, the examination procedures used in court would be taken up by the press as a valuable tool for collecting information from witnesses everywhere.

The practice of interviewing became increasingly common in America in the 1860s following a meeting between Horace Greeley of the New York Tribune and Brigham Young, the leader of the Mormon Church, in Salt Lake City and especially after the publicity given in 1867 to Joseph McCullagh's interview with soon-to-be- 
impeached President Andrew Johnson. While conversations with famous men have attracted most attention, Michael Schudson emphasizes the gradual acceptance over the next several decades of the interview as standard journalistic practice referring both to "a social interaction between a person of public interest and a professional writer and to the literary form that is the product of that interaction" (74). Newspapers had printed only verbatim transcripts of public speeches prior to the use of interviews, which were still unusual in the early 1870s (or early 1890s in England) although occasional direct quotations from public men indicated an increasing reliance upon interview methods. The rapid growth of the newspaper industry during this period made it possible to devote more resources than ever before to the active pursuit of news and, consequently, for specialized forms of journalism like interviewing to emerge. Horace Townsend explained the two approaches to news as a contrast between faith in official sources and skepticism toward commonplace statements that may conceal interesting facts if drawn out by close questioning. Journalists at first had regarded the interview as a news event in itself rather than an additional technique for gathering evidence. As audiences recognized, the journalist was no longer an anonymous byline in many of these interactions but a visible actor within the story itself. And by the 1880s and 1890s many of the same people who initially resisted the publicity associated with interviewing had learned how to turn this attention to their own benefit. As Julian Ralph of the New York Sun explained in his memoirs, "The feature of interviewing which most laymen fail to understand is that, seven in ten times, the man who is interviewed is glad of a chance to speak" (40).

The reluctance of the British press to adopt interviewing techniques until several decades after the American press meant that after moving abroad James was able to follow debates over their appropriate use for a second time. The interview was widely regarded as an American invention and, consequently, associated by many with "the Americanisation" of English journalism. ${ }^{3}$ British journalist Alfred Arthur Reade's Literary Success: Being a Guide to Practical Journalism (1885) describes interviewing as an extension of prominent national characteristics: "The interviewer is a creation of American civilisation, and arises out of the universal curiosity among Americans for the details of private life and the opinions of public men" (72). Similar responses made by other journalists expressed a fear that the British press was importing not just American journalism techniques but American values. Use of the interview confirmed for many nostalgic critics the degradation of a formerly respectable British press. All the Year Round melodramatically announced in 1892, "The plague of interviewing has spread to England. We fear the cholera; but this other pest, which, I verily believe, is at least as serious, we seem to welcome. . . Already interviewing is becoming, even in England, a regular profession" ("Interviews" 423). The following year in the Strand Magazine, caricaturist Harry Furniss's "Interviewed!” portrayed the celebrity pinned down like an entomological specimen, impaled through the chest with a quill pen before a photographer and a journalist who inspects his appearance through a magnifying glass (see fig. 1). Nevertheless, American and British interviewers were thought to adhere to conflicting codes of decorum when it came to obtaining information from private individuals. Whereas the British interviewer supposedly respected an unwillingness to be interviewed, the American interviewer recognized no such limits: "He desires to find his way into the most private places. With your leave, or without 


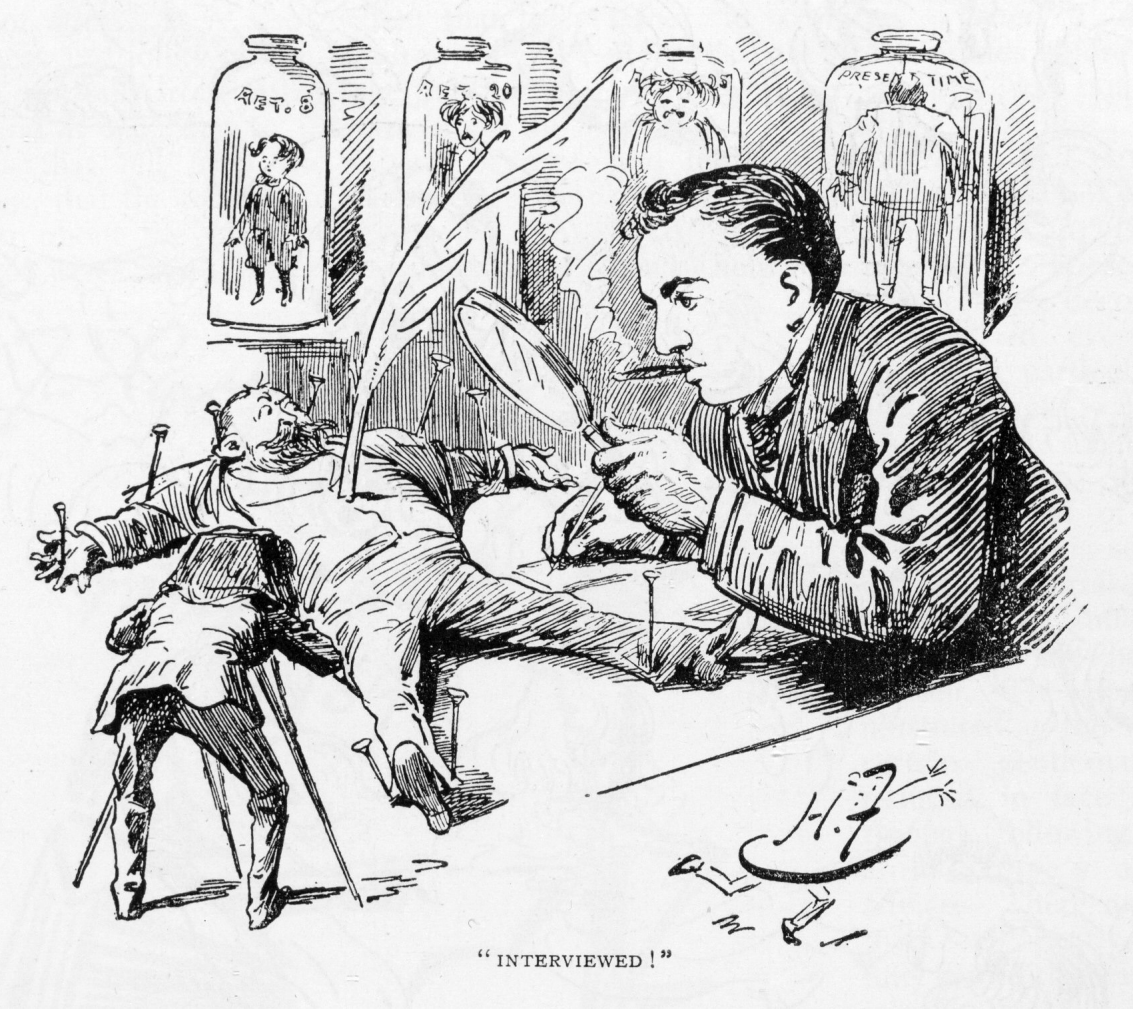

Figure 1. "Interviewed!" by Harry Furniss. Strand Magazine 5 (1893): 571.

your leave, that desire of his he does his best to realize" (422). Characterization of the American interviewer "willing to thrust himself anywhere" by The Journalist, a trade newspaper for the British press, did little to discourage this national distinction ("American Journalism" 12a). Queen Victoria reportedly said of one American journalist's attempt to interview her in a Scottish churchyard, "He is as audacious as the rest of his nation" ("Interviewing” $1 \mathrm{~g}$ ).

Successful attempts by American journalists to interview British public figures drove journalists in England to adopt interviewing techniques, although insistently without the American impertinence. Edmund Yates's "Celebrities at Home" series for The World during the 1880s was among the first to draw upon personal conversations, and W. T. Stead regularly interviewed public figures for the Pall Mall Gazette, most notably in the 1884 interview with General Gordon resulting in the Khartoum expedition. ${ }^{4}$ According to John Mackie's Modern Journalism: A Handbook of Instruction and Counsel for the Young Journalist (1894),

"Interviewing," as practised in connection with English journalism, is on a higher plane than that with which the American press has familiarised the world. It shows more respect for the sacred privacies and for the domestic 
sanctities. It is altogether less reckless, seeking rather to provide interesting information than to supply gossip or scandal. (58)

While Mackie may exaggerate the deference of British journalism, whose Sunday papers had provided the raw materials for the interview in America, his account nevertheless acknowledges the formal nature of newspaper publicity in Britain, where interviews typically took place with participants who had a favorable relationship with the periodical in question. As Alexander Innes Shand explained in Blackwood's, "If you prevail on a celebrity to let you interview him 'at home,' you give a pledge tacitly or in words that you propose to treat him considerately" (78). However, this idealized phase of unintrusive publicity could not last under a commercial press intent on finding new ways of attracting public attention.

Many writers on both sides of the Atlantic who shared James's distaste for publicity, such as E. L. Godkin, Mark Twain, Eliza Lynn Linton, Evelyn March Phillips, and Arthur Shadwell, complained that the interview was not too personal but too trivial. In their accounts, the only threat posed by the interview was to the reader's patience. Interviewers increasingly emphasized the speaker's presence through detailed attention to appearance, mannerisms, lifestyle, and conversation; incidentals of the meeting were at least as important as actual conversation. Parodies such as "The Interviewer's Vade Mecum" appearing in Punch gave currency to this notion of the vacuous interview in which a figure's attire was likely to receive more attention than the accomplishment for which he or she was admired:

Q[uestion]. Which would be the better copy-an account of the subject's most successful campaign, or a description of his wardrobe?

A[nswer]. Undoubtedly the latter. The exploits will certainly have been described a score of times, but a list of coats, hats and neckties will probably have the charm of novelty.

Q[uestion]. Then you would not value your subject's diary?

A[nswer]. Not if it merely recorded his public life. In such a case it would be distinctly less interesting than his butcher's book.

Daniel Borus has described how publishers were able to present the "author at home," an informal conversation with the writer in a domestic setting, as a way of converting the artist into a literary personality for public consumption. ${ }^{5}$ Stories such as "The Death of the Lion" (1894) might be read in this context as a satire not only of literary publicity but also of James's fellow authors who agreed to be profiled in order to succeed in the marketplace. It was in this commercial environment that James insistently distinguished between the author and the author's work, saying of virtuoso soprano Adelina Patti, "After you have heard a Patti sing why should you care to hear the small private voice of the woman?" (Brooks 1). James's own refusal to speak with the press - he gave only three interviews in his lifetime-is noteworthy for taking place during the very decades in which the British public had become more interested in reading about the lives of authors than at any previous point in history. ${ }^{6}$ However, this version of degrading publicity may say more about the author's privileged position within the literary marketplace than the actual interests of reading audiences, many 
of whom would have read an author's butcher's book as a complementary pleasure to the reading of his literature.

James wrote The Reverberator at a time when the interview was just becoming a popular means by which people made sense of their own lives through the act of reading about the lives of others. The periodical press played a key role in promoting this form of cultural visibility especially familiar to audiences of the intimate public sphere arising in the twentieth century. Audiences by now familiar with interview conventions expected a face-to-face encounter between two people to result in a published conversation disclosing the speaker's true self. Sociologists Paul Atkinson and David Silverman have argued that the very act of confession encourages audiences to feel an intimate connection to the speaker no matter how predictable the nature of the personal revelations. The first-person voice is persuasive evidence of an individual's hidden self otherwise known to audiences only through impersonal images circulated by the mass media. For this reason, interview methods have been criticized by many sociologists who advocate constant awareness of the media apparatus responsible for the seemingly unmediated self-presentation. This coherent life narrative is instead "always pastiche," in the words of Atkinson and Silverman, or retrospectively put together from select memories and memorabilia (319). The two most common approaches to interviewing presuppose that narrative acts reveal, as opposed to create, a speaker's identity: in the one, the supportive interviewer's questions facilitate the spontaneous emergence of the genuine self; in the other, the hostile interviewer strips away layers of deception in order to reveal the hidden self. Both models take for granted that the journalist has only to ask the right questions in order to uncover the respondent's character. Disagreement over the interview's ability to represent identity in this way might be framed through two conflicting optical metaphors used by journalists in the nineteenth century to characterize the interview as either "a clear sheet of plate glass" or “a convex mirror" (Barr 341; "Editor's" 971). For James, the interview was never without a mirror's distortion, although such a realization does little to explain why his fiction emphasizes precisely those characters most interested in reading about other people's private lives.

A brief plot summary of The Reverberator may be helpful since the short novel is not one of James's best-known works. This jeu d'esprit, as he refers to the narrative in the preface to the New York Edition, first appeared as a serial in Macmillan's Magazine from February to July 1888 before coming out in separate one- and twovolume editions for England and America. Inspired by an actual case in which a young American woman wrote an indiscreet letter describing Venetian society for the New York World, it tells the story of the engagement between Francie Dosson, an ingenuous American girl visiting France with her family, and Gaston Probert, a Gallicized American whose aristocratic family despises publicity of any sort. The trouble begins when Francie indiscreetly reveals the Probert family secrets to her rejected suitor George Flack, the correspondent of a fictional American society newspaper called the Reverberator. The contrasting receptions given to Flack's scandalous letter when it appears in the newspaper form the basis for this international-themed comedy. The Probert family's indignant, if hypocritical, reaction leads to the temporary breakingoff of the engagement, although Gaston eventually goes against his family's wishes by choosing to marry Francie anyway in what turns out to be one of James's few unambiguously happy endings. 
The Reverberator is James's only novel to take newspaper journalism as its primary subject rather than isolating it in minor characters such as Matthias Pardon or minor attributes of characters such as Merton Densher. Although inspired by an indiscreet letter written to the newspaper by Miss May McClellan, James's novel splits its female source into the twin figures of Francie Dosson (a "newspaperized American girl”) and George Flack ("a journalist, of the most enterprising, and consequently of the most vulgar, character") (CN 41). In doing so, the novel goes against a contemporary stereotype of the female journalist's innate advantages for conversation, a notion raised in earlier novels by the New Woman attitudes of Henrietta Stackpole

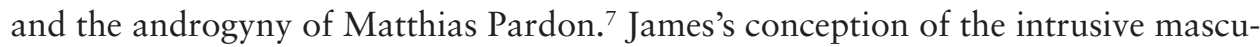
line journalist finds its initial expression in Flack, whose ambition to transform the Reverberator into the world's leading society paper borders upon self-parody:

I'm going for the secrets, the chronique intime, as they say here; what the people want is just what isn't told, and I'm going to tell it. Oh, they're bound to have the plums! That's about played out, any way, the idea of sticking up a sign of "private" and thinking you can keep the place to yourself. You can't do it-you can't keep out the light of the Press. Now what I am going to do is to set up the biggest lamp yet made and to make it shine all over the place. We'll see who's private then! (RE 61)

Flack's mission to provide "the plums," or sensational stories about private life, perpetuates the stereotype of the journalist peeping through windows and behind closed doors. The lamp metaphor elaborated throughout the novel further promotes the image of an intrusive press bringing to light a concealed private life. Yet this image of the invasive journalist is misleading. It is comparable to accusing the lights on a film set of giving unwanted attention to the lead actor. As with Pardon's self-promoting prime donne, the social elite will be the ones who furnish the scandalous intelligence appearing in Flack's newspaper: “The society news of every quarter of the globe, furnished by the prominent members themselves (oh, they can be fixed-you'll see!)" (60-61). The role of the press can hardly be deemed invasive when the grand monde itself is providing the plums. Flack's is an exaggerated perspective within the novel but not as exaggerated as James's dismissive remarks in the notebooks may lead us to believe. In fact, the Dossons confirm this view of a publicity based on voluntary participation over violated privacy. Flack envisions a society that has internalized newspaper journalism to the degree that audience members participate in the reception as well as the production of scandal, even-or especially-when that scandal should happen to involve those very readers.

It should be born in mind that Flack is not an investigative reporter but a Paris correspondent whose personal impressions appear in intimate letters to an American journal. He specializes in "the interviewing business" (RE 64) and, like James's other journalists, is said to lack "delicacy," "discretion," and "reserve" (CN 41) when it comes to deciding what news is fit to print: "Every one has something to tell, and I listen and watch and make my profit of it" (RE 115). Yet in spite of this image of the prying reporter, Flack characterizes his role in very different terms as a form of editorial gatekeeping. He is in many ways opposed to the investigative reporter when 
it comes to collecting information "straight from the tap": "People just yearn to come in; they're dying to, all over the place; there's the biggest crowd at the door. But I say to them: 'You've got to do something first, then I'll see; or at any rate you've got to be something!'” (117). The image of the crowd "dying" to tell their stories effectively reverses the novel's earlier image of a sign marked "private," for it is not the public who shuts the door on Flack but rather Flack who shuts the door on the public. The unremarkable individuals admonished by Flack to "do something" or "be something" setting themselves apart from the crowd expect the newspaper to generate, not report, their fame. These readers aspire to a distinctly modern version of celebrity in which one could be famous simply for being famous. ${ }^{8}$

Then there is the Dosson family's own interest in reading about celebrities. Delia Dosson longs to infiltrate an elite circle of Americans abroad encountered only through the newspapers, or, in the narrator's words, "that select body which haunted poor Delia's imagination, glittered and re-echoed there in a hundred tormenting roundabout glimpses" (42). The tantalizing images "re-echoed" through Delia's mind align her with Flack's Reverberator, which reflects society back to itself via mediated images that, as the echo suggests, inevitably take on a life of their own. The glittering fragments about which Delia cannot stop thinking promise a satisfying, if endlessly deferred, experience available only through the newspaper's mediation. The spatial terms used to portray Delia's media-induced yearning can be seen to map out a virtual "inside" defined only through visibility in print. James would later describe newspaper publicity as a citadel closed off to outsiders in "The Papers" in much the same way as Delia perceives here "a little kingdom of the blest" known only through the newspapers: "That was where she wanted to get Francie, as she said to herself; she wanted to get her right in there" (42). The newspaper represents and even replaces intimacy for Delia, who, having already met Gaston Probert, reverses the conventional order of social interaction by asking Flack to profile Probert "as if it would be in the natural course that he should elicit the revelation by an interview" (41). Delia goes from reading about strangers whom she would like to meet to meeting strangers about whom she would like to read.

Delia's ambition to become part of the grand monde known only through the newspapers explains her sister Francie's willingness to forego her own privacy in order to assume a place within the public sphere. Thus Francie's lesson about the perils of interviewing comes less through the chiding of the Proberts than through its interference with her marriage prospects. Flack's forthcoming manner absolves the journalist of sole responsibility for publishing the controversial interview that will endanger Francie's engagement. "Of course I must be quite square with you," Flack tells her in the Bois de Boulogne, "If I want to see the picture it's because I want to write about it. The whole thing will go bang into the Reverberator. You must understand that, in advance" (121). There are no sly interrogative tricks as were used in the infamous case of Julian Hawthorne and James Russell Lowell. ${ }^{9}$ Here as elsewhere the journalist establishes consent prior to the interview. "You may say what you like," Francie tells her interviewer, "It will be immense fun to be in the newspapers" (121). Ingenuous as she may be, Francie expresses a pleasure in publicity that James usually addressed through caricature or outright contempt. In fact, Flack's unromantic willingness to accept an interview in lieu of marriage needs to be interpreted within the context of 
Francie's anticipated pleasure, which presumably arises from her recollections of reading about other people in the papers. The parallel drawn between the marriage proposal at Saint-Germain and the interview in the Bois underscores the meeting's intimacy. Hence Flack's vicarious participation in Francie's personal life through the interview comes so close to the real experience that the two are practically indistinguishable: "You make me feel quite as if I were in the grand monde" (132). There is no sense of resentment at how the interview allows Flack to feel part of a circle owing its very prestige to the exclusion of outside observers like him. Instead, Flack feels what he intends to make the Reverberator's audience feel while reading the conversation, which, as Flack's words intimate, offers a chance to experience someone else's life. Flack's affective identification with Francie through the interview-"You make me feel quite as if I were in the grand monde"-anticipates a form of behavior described by psychologists today as "parasocial interaction" to explain how audiences develop intimate relationships with personalities known only through media images (Rubin 279). Hence Flack recognizes that he will paradoxically be part of Francie's life to a greater degree when he is not with her than when he is with her. In this sense, reading about other people could at the same time be a way of reading about one's self.

James's novel ultimately is set apart from contemporary indictments of journalism by its recognition that the journalist's behavior is of little consequence as long as ingénues like Francie (or May McClellan, for that matter) insist on speaking to the press. The Proberts' indignant reaction to Flack's interview resembles that of readers who interpret James's narrative as an invasion of privacy: both want to blame the press for the act of a willing agent. Flack's status as a "newspaperman," an even less reputable designation than "journalist" in the 1880s, makes him a convenient scapegoat. At the same time, the Proberts insist on Francie's remaining "stainless," or in no way complicit with the press, even though the metaphor ironically evokes the narrative's earlier image of Francie's ink-stained finger, an established trope (along with Flack's crooked forefinger) at the time for press work (139). Gaston's characterization of journalism as "pollution" expresses the family's anxiety about Francie's contaminating entrance into the family circle (190). Thus Madame de Brécourt is surprised by Francie's refusal to participate in the rhetoric of victimhood that enables the Proberts to maintain their superiority in the face of degrading scrutiny: "Oh, Francie, don't say it—don't say it! Dear child, you haven't talked to him in that fashion: vulgar horrors, and such a language!” (137). Since Francie speaks the English of the newspapers, her admission into the family's French salon hinges upon absolution of the journalistic taint-figuratively, the ink stains on her fingers-by attributing full responsibility to Flack. Even Gaston pleads with her to assume the appropriate role as the journalist's victim: "That you told him—that you told him knowingly. If you'll take that back (it's too monstrous!) if you'll deny it and declare you were practised upon and surprised, everything can still be arranged" (187). Ultimately the sundering takes place because of Francie's intolerable attitude toward the American press rather than her indiscretion: she believed the family would like being talked about in the newspapers. The Proberts, of course, make no distinction between favorable and unfavorable publicity in their disgust at being "served up to the rabble" (136). The family dreads exposure to their neighbors through the story's imminent syndication in the French press only slightly more than its reception among distant readers whom they 
will never encounter; as Madame de Brécourt says of the story's reception overseas, "So many people in America-that's just the dreadful thought, my dear" (145). The family's vulnerability to unsympathetic interpretation by strangers with little sense of the salon's codes, values, and traditions accounts for their sense of violation even in the absence of actual reader responses.

The interviewer's presence in an otherwise conventional romance thus makes it possible for James to explore how characters respond to what Schudson calls the "overhearing audience," an unseen third party in a triangulated relationship with interviewer and interviewee (75). Even when the journalist reporting the conversation refrains from explicit evaluation in such cases, there is always an inferred evaluation by the implied public, whose presence if known would certainly alter the behavior of those under its scrutiny. As one of James's contemporaries, W. L. Alden, observed, "The man who submits to an interview knows that he is talking for publication" (Linton 498). This third presence reminds us that our behavior is being observed, that we are being appraised by outside eyes. It forces us to alter not just what we say but how we say it - a form of anticipation Erving Goffman referred to as "impression management" (13). Perhaps there is no greater sign of intimacy in James than the wordless communication between two characters whose thoughts are so in tune that there is little need for speech. The interview provides the inverse model of speech: meaning must be made explicit and unequivocal for comprehension by outsiders. Consequently, many conversations in James that do not have the formal structure of the interview nevertheless have the premise of the interview behind them. We see this in numerous episodes of Jamesian dialogue in which characters with virtuoso skill manipulate, misdirect, evade, and deflect questions without ever formulating a clear response that might put them at a disadvantage in terms of the balance of information. In this sense, the interview in James's fiction may not be a problem limited solely to interaction with the journalist but applicable to all conversation that relies on the tactics of withholding and revealing information with an audience, seen or unseen, in mind.

The Reverberator thus introduces a model of reading appropriate to an interview society in which the strategies of revelation and concealment have become almost second nature. In his discussion of literacy within mass culture, Thomas Strychacz has proposed "affirmative publicity" as the novel's third term in between the models of misreading represented by the Dossons' publicity and the Proberts' privacy (55). While absent from the narrative itself, this definition of modernist literary competence presumably precedes or arises during the reader's interaction with the text. As appealing as this conception of the Jamesian interpretive community may be, however, it dismisses too quickly the prescriptive models of reading found throughout the narrative. ${ }^{10}$ One ideal image of the self-awareness James sought to instill in the novel's readers comes through Francie's reconsideration of her family's complicit role in reading the newspapers:

Perhaps they had got coarse and callous, Francie said to herself; perhaps they had lost their delicacy, the sense of certain differences and decencies. Then ... she thought of the lively and chatty letters that they had always seen in the papers and wondered whether they all meant a violation of 
sanctities, a convulsion of homes, a burning of smitten faces, a rupture of girls' engagements. (158-59)

The style of reading advocated by these interruptions makes use of journalism's resources while at the same time remaining aware of the media through which a conversation reaches its audience. These hypothetical scenarios (violated sanctities, convulsed homes, smitten faces, and ruptured engagements) nowhere stated in the actual letters express Francie's dawning awareness of what a published conversation may conceal through the very gesture of revelation. The passage is remarkable for its refusal to blame the journalist. Francie's revised reading style neither celebrates journalism, as the Dossons once did, nor turns a blind eye to it, as do the Proberts. A third approach takes into account how newspaper reportage can just as easily operate as a screen. After all, as Francie comes to realize, the incriminating portions of Flack's letter are to be found in "the allusions" (157). The lesson notably comes to the novel's most naïve reader, whose reversal takes place only after recognizing what has been left unsaid in her own interview for the Reverberator.

Still, Francie's reversal would be little more than a moralizing digression if not for its relevance to subsequent scenes of James's novel that make little, if any, literal sense without this revised approach to interpreting dialogue. The most important of these scenes occurs when Gaston shares his ambiguous impressions of America with Mr. Dosson:

“Well, what didn't you like?" Mr. Dosson genially inquired.

Gaston Probert hesitated. "Well, the light for instance."

"The light-the electric?"

"No, the solar! I thought it rather hard, too much like the scratching of a slate-pencil." (185)

One can hardly blame Mr. Dosson for his blank-faced response. (Dodie Smith's theatrical adaptation of the novel has Delia confusedly ask at this point, "The light was like a slate pencil?" [77]). The dialogue thwarts literal interpretation unless one concedes that the American sunlight is capable of making such a curious impression on visitors. The remark is not taken this way by Mr. Dosson, however, who mistakenly assumes Gaston is speaking about a "great lamp company" with which he is unfamiliar (185). The figurative language of the dialogue makes sense only to an audience who has been following the narrative's elaborate metaphor for the press from its earliest mentions as part of Flack's vision of the press as "the biggest lamp yet made" and the "great shining presence" of the time $(61,22)$. In this regard, Flack's "brilliant" interview is just one of the novel's many conversations to take place beneath carefully arranged lighting (lamps, fireplaces, sunlight) of varying intensity $(57,157)$. Conversely, Gaston returns from America noticeably "sunburnt" by the glare of publicity, and Francie's disaffection with the press can be traced from her initial "brightness" at being in the papers to a face with "no bright flicker" that greets Gaston after the scandal (164). Mr. Dosson nevertheless remains oblivious to the connotation (or denotation, for that matter) of Gaston's metaphor; the audience alone can comprehend the conversation whose full import is available only through the method of reading modeled by Francie's recognition of a potential story behind the story. 
In a novel about the effects of publicity upon private conversation, the most significant emotional exchange notably takes place outside the boundaries of dialogue altogether. Whereas Flack is unable to distinguish between the two meanings of the interview, that of a conversation between two people and that of a conversation reproduced for a third party-in this case, the more than 200,000 subscribers to the Reverberator-Gaston successfully cultivates an intimacy bypassing speech altogether. Thus at the very moment in which Francie declares the engagement to be over, a contrary course of events is set in motion outside the quotation marks: "Ah, I'm not worth it. You give up too much!' cried the girl. 'We're going away-it's all over.' She turned from him quickly, as if to carry out her meaning, but he caught her more quickly still and held her-held her fast and long" (198). Speech means the opposite of what it says in this scene, in which reconciliation is apparent only by observing how the unspoken interaction contradicts the spoken words "it's all over." Even so, this scene would be little more than a conventional reconciliation between lovers were it not for the interruption by Mr. Dosson and Delia: "Oh, I thought you had at least knocked over the lamp!" (198). The two lovers have knocked over the lamp by creating a space for themselves apart from the light of the press. Through this silent gesture, Gaston and Francie establish an unspoken intimacy that would scarcely be perceptible if read in the manner of an interview. The ruptured engagement Francie imagines to be implicit in all newspaper correspondence is effectively reversed through this reconciliation away from the light of the press. Flack's final letter to the Reverberator ironically ensures their privacy by mistakenly reporting Francie's marriage to have been called off - the next best thing to sticking up a sign marked "private."

As the novel's scenes of reading indicate, The Reverberator ultimately poses a larger formal question about the degree to which the experience of reading an interview and reading a novel should be taken as analogous acts. The parallel is unmistakable. In both situations the reader acts as an invisible third party to a conversation between two people: in the one, a character's dialogue takes place as if unaware of a potential audience; in the other, a character self-consciously directs the conversation toward an implied audience. (James's dismissive remarks about first-person narration in the preface to The Ambassadors and elsewhere noticeably resemble his criticisms of journalistic writing.) James might be said to invoke the comparison through scenes of dialogue that eliminate the boundary between personal conversation and professional journalism. Not only does Flack's initial intimacy with the Dossons come through recounting aloud the day's celebrity interviews, but even a personal conversation between Flack and Delia proceeds along the lines of a professional interviewer "drawing out" a respondent for the benefit of an unseen third party: "If an auditor had happened to be present for the quarter of an hour that elapsed and had had any attention to give to these vulgar young persons he would have wondered perhaps at there being so much mystery on one side and so much curiosity on the other" (10). The twin poles of "curiosity" and "mystery" should by now be familiar to us as the asymmetrical arrangement between interviewer and interviewee, even if the subsequent conversation makes one wonder why James would bother to invoke an imagined third party for the occasion at all. The auditor who appears to be little more than the author's rhetorical sleight of hand turns out to be maintained for the entire conversation. Yet 
this third party, described by the narrator as the "observer whom we have supposed to be present," is superfluous since the editorial "we" already assumes an audience addressed by the narrator (13). Introducing the hypothetical observer enables James to prescribe an appropriate reaction lest the audience, contrary to the author's intention, should mistakenly empathize with the two conversationalists or even with the novel itself as a kind of conversation with the author, as Barbara Hochman has argued audiences persisted in doing long after the turn toward impersonal narration at the close of the nineteenth century (7). The characters are permitted to tell their own stories here under condition that the anonymous narrator, or in this case the anonymous narrator's proxy, is given the last word.

James's written record would lead us to conclude that he opposed interviews published without the speaker's consent, but often in James's novels we find the opposing situation in which a speaker desires to have his or her words reprinted for an outside audience. Under such conditions characters deliberately alter their speech in order to present themselves, to borrow James's metaphor, in the most favorable light. Francie's reading lesson suggests that the skepticism with which a reader approaches fiction, where characters cannot know their words are being overheard, should not be set aside when reading journalism, where speakers know their words are being overheard. We are asked to recall Francie's conversation with Flack in the Bois de Boulogne not as a way of evaluating the fairness of the published interview but as an occasion for asking whether this mode of journalism can adequately represent a life at all. As audience to the novel, we know what readers of the interview alone will never know: Flack's failed proposal at Saint-Germain, Francie's indebtedness to the journalist, the Probert family's predictable displeasure. Thus when Francie later becomes a disillusioned reader of the published interview, her stance might be taken to correspond with the implied reader's own position. We are asked to approach the interview with the same hermeneutic sophistication with which we would analyze dialogue in a novel-particularly a Jamesian novel in which character emerges gradually through what is said as well as what is not said. This careful distinction reflects James's awareness of how close his own role as author could be at times to that of the journalist writing about other people's private conversations. A novel originally based on reports of a young woman's indiscretion certainly risked being perceived as a roman à clef no different from the material it claimed to be satirizing. By making this material into a story at all, James ran the risk of himself being perceived as a journalist using his "interviewees" for personal gain. The Reverberator might even be read as James's way of working through his own ambivalence toward the authorial use of other people's conversations by emphasizing what ultimately sets the art of fiction apart from the art of interviewing. While James's hostility toward the interview may seem anachronistic today, his insistence that we read the interview as another form of fiction remains as applicable now as it did at the turn of the century.

\section{NOTES}

I would like to thank the University of Pennsylvania's Humanities Forum for an Andrew W. Mellon Fellowship that supported the writing of this article.

${ }^{1}$ Recent considerations of James and newspaper journalism include Burns, DaRosa, Kramer, Reid, Salmon, Strychacz, and Thomas.

${ }^{2}$ Malcolm gives one of the most controversial accounts of the confessional aspects of journalism. 
${ }^{3}$ References to the interview as an American "invention" and to the "Americanisation" of the British press were common in discussions of nineteenth-century journalism, as shown in works by Dennett and Stead.

${ }^{4}$ For a discussion of the interview's earliest use in England, see Brown (160-66).

${ }^{5}$ See also Salmon's account of the literary interview in "The Author at Home" section of Henry James and the Culture of Publicity (106-10) and more broadly in "Signs of Intimacy."

'James's interviews include those with Florence Brooks (1904), Witter Bynner (1905), and Preston Lockwood (1915). The Brooks and Lockwood interviews are reprinted in Walker (35-41; 138-45). See also Antsyferova. More recently, Ozick's “An (Unfortunate) Interview with Henry James” (2005) has imagined how a fourth interview might have appeared.

${ }^{7}$ For an account of the gendering of journalism in James's fiction, see Kramer.

${ }^{8}$ This is Boorstin's classic formulation of the tautological nature of celebrity.

${ }^{9}$ For an account of the Hawthorne-Lowell affair, see Knox.

${ }^{10}$ The model of the implied reader used here comes from Stewart's idea of the "conscripted audience" encoded in the narrative through the rhetorical devices of interpolation (direct address) and extrapolation (scenes of reading). Stewart cites one of James's comments on reading in order to distinguish his analysis of the nineteenth-century audience from the limited models offered by reader response and cultural studies: "In every novel the work is divided between the writer and the reader; but the writer makes the reader very much as he makes his characters" (6).

\section{WORKS BY HENRY JAMES}

BO-The Bostonians. New York: Vintage, 1991.

CN-The Complete Notebooks of Henry James. Ed. Leon Edel and Lyall H. Powers. New York: Oxford UP, 1987.

PL-The Portrait of a Lady: An Authoritative Text, Henry James and the Novel, Reviews and Criticism. Ed. Robert D. Bamberg. New York: Norton, 1995.

RE-The Reverberator. New York: Grove, 1957.

\section{OTHER WORKS CITED}

“American Journalism II.--Interviewers." The Journalist 7 January 1887: 12a.

Antsyferova, Olga. “Three Interviews of Henry James: Mastering the Language of Publicity.” Henry James Review 22 (2001): 81-92.

Atkinson, Paul, and David Silverman. "Kundera's Immortality: The Interview Society and the Invention of the Self." Qualitative Inquiry 3.3 (1997): 304-25.

[Barr, Robert]. "A Chat with Conan Doyle.” The Idler 6 (1894): 340-49.

Boorstin, Daniel. The Image: A Guide to Pseudo-Events in America. New York: Harper, 1964.

Borus, Daniel. Writing Realism: Howells, James, and Norris in the Mass Market. Chapel Hill: U of North Carolina P, 1989.

Brooks, Florence. "Henry James in the Serene Sixties.” New York Herald 2 Oct. 1904, magazine supplement: 1.

Brown, Lucy. Victorian News and Newspapers. Oxford: Clarendon, 1985.

Burns, Allan. "Henry James's Journalists as Synecdoche for the American Scene.” Henry James Review 16 (1995): 1-17.

Bynner, Witter. "A Word or Two with Henry James." The Critic and Literary World 46.2 (1905): $146-48$.

DaRosa, Marc. "Henry James, Anonymity, and the Press: Journalistic Modernity and the Decline of the Author." Modern Fiction Studies 43.4 (1997): 826-59.

Dennett, J. R. "Interviewing." The Nation 8 (1869): 66-67.

“Editor's Easy Chair.” Harper's New Monthly Magazine 70 (1885): 971-72.

Flaubert, Gustave. Bouvard and Pécuchet with the Dictionary of Received Ideas. Trans. A. J. Krailsheimer. New York: Penguin, 1976.

Goffman, Erving. Strategic Interaction. Philadelphia: U of Pennsylvania P, 1969.

Hochman, Barbara. Getting at the Author: Reimagining Books and Reading in the Age of American Realism. Amherst: U of Massachusetts P, 2001.

“The Interviewer's Vade Mecum.” Punch 108 (1895): 112.

"Interviewing the Queen.” New York World 17 June 1883: 1g.

"Interviews and Interviewing." All the Year Round 3rd ser. 8 (1892): 422-26.

Knox, George. “The Hawthorne-Lowell Affair.” New England Quarterly 29 (1956): 493-502.

Kramer, David. "Masculine Rivalry in The Bostonians: Henry James and the Rhetoric of 'Newspaper Making." Henry James Review 19 (1998): 139-47.

Linton, Mrs. Lynn, et al. “Are Interviewers a Blessing or a Curse?” The Idler 7 (1895): 491-98. 
Lockwood, Preston. “Henry James’s First Interview.” New York Times 21 March 1915, magazine section: $3-4$.

Mackie, John B. Modern Journalism: A Handbook of Instruction and Counsel for the Young Journalist. London: Crosby Lockwood, 1894.

Malcolm, Janet. The Journalist and the Murderer. New York: Vintage, 1990.

Nilsson, Nils Gunnar. “The Origin of the Interview.” Journalism Quarterly 48 (1971): 707-13.

Ozick, Cynthia. "An (Unfortunate) Interview with Henry James.” The Threepenny Review 100 (2005) $<$ http://www.threepennyreview.com/samples/ozick_w05.html>.

Ralph, Julian. The Making of a Journalist. New York: Harper, 1903.

Reade, Alfred Arthur. Literary Success: Being a Guide to Practical Journalism. London: Wyman, 1885.

Reid, Michael. "The Repressing of the Journalistic in The Wings of the Dove." Henry James Review 19 (1998): 239-44.

Rubin, Rebecca, and Michael P. McHugh. "Development of Parasocial Interaction Relationships.” Journal of Broadcasting and Electronic Media 31 (1987): 279-92.

Salmon, Richard. Henry James and the Culture of Publicity. Cambridge: Cambridge UP, 1997. - "Signs of Intimacy: The Literary Celebrity in the 'Age of Interviewing." Victorian Literature and Culture 25.1 (1997): 159-77.

Schudson, Michael. "Question Authority: A History of the News Interview." The Power of News. Cambridge: Harvard UP, 1996. 72-93.

Sennett, Richard. The Fall of Public Man. New York: Knopf, 1977.

[Shand, Alexander Innes]. "Contemporary Literature-II. Journalists and Magazine-Writers.” Blackwood's Edinburgh Magazine 125 (1879): 69-92.

Smith, Dodie. Letter from Paris. London: William Heinemann, 1954.

Stapleton, Stephen. “Society Journalism.” Monthly Review 21 (1905): 102-14.

Stead, William Thomas. The Americanization of the World. New York: Garland, 1972.

Stewart, Garrett. Dear Reader: The Conscripted Audience in Nineteenth-Century British Fiction. Baltimore: Johns Hopkins UP, 1996.

Strychacz, Thomas F. Modernism, Mass Culture, and Professionalism. Cambridge: Cambridge UP, 1993.

Thomas, Brook. "The Construction of Privacy in and around The Bostonians." American Literature 64.4 (1992): 719-47.

Townsend, Horace. "Interviewing as a Factor in Journalism." North American Review 148 (1889): 522-23.

Walker, Pierre A., ed. Henry James on Culture: Collected Essays on Politics and the American Scene. Lincoln: U of Nebraska P, 1999. 
ever-after a story of ugliness and horror and pain.

Rubery, Matthew.

- Wishing to Be Interviewed in Henry James's The Reverberator

[Access article in HTML] [Access article in PDF]

Subjects:

- James, Henry, 1843-1916. Reverberator.

- Press and journalism in literature.

Abstract:

While Henry James's journalists have long been taken as the author's protest against the invasion of privacy, this essay suggests that it is not the journalist who poses the greatest threat to privacy but rather the public itself. James's fiction addresses people's willingness to share their most intimate experiences during the journalistic interview in a way that ran counter to James's own preference for impersonal narration. A reading of James's The Reverberator suggests the interview may be a problem whose implications reach well beyond the limited interaction with the journalist to all conversation involving the selective disclosure of information with an unseen audience in mind.

Storm, William, 1949-

- The "Impossible" Miriam Rooth: Performance, Painting, and Spectatorship in The Tragic Muse [Access article in HTML] [Access article in PDF]

Subjects:

- James, Henry, 1843-1916. Tragic muse.

o James, Henry, 1843-1916 -- Characters -- Miriam Rooth.

- Rooth, Miriam (Fictitious character)

Abstract:

The Tragic Muse embodies the problem of how arts other than the literary (primarily theatrical performance and portraiture) are conveyed in narrative, an aesthetic issue reflected chiefly in the elusive and contradictory aspects of actress Miriam Rooth. One reference to Miriam ("beautiful actual fictive impossible") reflects James's sense of contrary qualities that arise partly because she is portrayed only through spectatorship-- the altering observations of other characters. Miriam's histrionic temperament, and her varied acting roles, add to what is finally a problem of representation itself, particularly in regard to how visual and kinetic arts coexist in narrative, albeit "scenic," description.

Meyers, Jeffrey.

- "Daisy Miller" and the Romantic Poets [Access article in HTML] [Access article in PDF] Subjects:

o James, Henry, 1843-1916. Daisy Miller. 
Reproduced with permission of the copyright owner. Further reproduction prohibited without permission. 